\title{
Childhood
}

\section{The Ignored Audience \\ A multi-method reception study on children and television news in Albania}

\begin{tabular}{|r|l|}
\hline Journal: & Childhood \\
\hline Manuscript ID & CHD-16-0013.R3 \\
\hline Manuscript Type: & Original Manuscript \\
\hline Keywords: & Television news, children, Albania, reception, political socialisation \\
\hline Abstract: & $\begin{array}{l}\text { Children are not considered to be an appropriate audience for news } \\
\text { coverage based on their presumed lack of emotional maturity, critical } \\
\text { thinking and proper knowledge. This article challenges these views by } \\
\text { presenting the opinions of children aged 10-15 who report having watched } \\
\text { broadcast news nearly every day. Additionally, the views of adults aged } \\
\text { 25-62, are investigated. Children contest to the ways they are being } \\
\text { portrayed by the news media and demonstrate their need to be considered } \\
\text { as active participants in the public sphere, which is presented by the news } \\
\text { media as an exclusive domain for adults. }\end{array}$ \\
\hline
\end{tabular}

\section{SCHOLARONE ${ }^{m}$}

Manuscripts 


\title{
A multi-method reception study on children and television news in Albania
}

\begin{abstract}
Children are not considered to be an appropriate audience for news coverage based on their presumed lack of emotional maturity, critical thinking and proper knowledge. This article challenges these views by presenting the opinions of children aged 10-15 who report having watched broadcast news nearly every day. Additionally, the views of adults aged 25-62, are investigated. Children contest to the ways they are being portrayed by the news media and demonstrate their need to be considered as active participants in the public sphere, which is presented by the news media as an exclusive domain for adults.
\end{abstract}

Keywords: Television news, children, Albania, reception, political socialization

News has generally been perceived as a genre that is not appropriate or even dangerous for children (Gunter, Furnahm and Griffiths, 2000). They are usually considered to lack the emotional maturity, critical thinking skills or the proper knowledge for making sense of the news. These views on children are aligned with the development psychology approach (Piaget and Inhelder, 1969), which classifies childhood in terms of "ages and stages", and as a linear progression towards entry into adulthood. According to James, Jenks and Prout (1998) within this tradition, children are understood as "becoming adults", as incomplete and incompetent social actors with respect to adults. As a result, Buckingham (2000) argues that children are prevented from engaging and contributing to society in a meaningful way.

On the other hand, the genre of news is considered to be an essential source of information that acts as a teacher of values, ideologies, and beliefs for citizens, while providing images to interpret the world (van Dijk, 2008). The same applies to children. The lack of a presence of children among general news coverage brings into question the potential of the media to facilitate the ways children connect with society (Carter and Davies, 2005).

The purpose of this study is to hear from children what they think about television news and their own portrayal. Albania is of particular interest, keeping in mind that the country of only 2.8 million people is home to a disproportionately high number of television channels. In addition to the public broadcaster (RTSH), there are two private national television channels, 71 private local television channels, and 83 private cable television channels currently operating in Albania (AMA, 2014). Furthermore, eight television channels broadcast only news (Kevin, Pellicano and Scheenberger, 2013). All news channels are privately owned and freely available in most of the country's territory. It is difficult to assess 
the opportunities for news consumption in Albania, as there is no credible or systematic audience research publicly available.

Nevertheless, a study conducted with the support of the European Commission (Nelaj, 2014) found that $73 \%$ of the Albanian population placed their highest level of trust in television news outlets when compared to other media. While no study currently exists on children's consumption of the news, it may be due to the fact no news service targeted towards children is offered by any of the television channels currently operating in Albania. The way in which children see themselves represented in news coverage is still unknown. Taking this context into consideration, researching the views of children aged 10-15 on television news, becomes a prerequisite to exploring how the news media addresses this particular group.

In this article, the term 'children' is used to refer to the age group 0-18 years, following the United Nations Convention of the Rights of the Child (UNICEF, 1989). Research on children as a news audience has typically examined children aged 15-18, due to the positioning of this specific age group on the boundaries of becoming 'citizens' (see Meijer 2007). When a younger age group is considered, such as 10-15 (see Carter et al., 2009; Buckingham, 2000) it has mostly been researched in relation to children's television news format, while in most countries such programs do not exist. Therefore, the views of children aged 10-15 on news media, still remain unexplored. This study addresses this age gap.

The present study acknowledges children as active participants in social life and as actors with potential for having agency of their own(Prout and James, 1997). In the context of news coverage, this means that children are capable of forming and articulating their own opinions regarding the news in general, and particularly their own portrayal. The views of adults on the same topic were investigated, with the study's aim being to check for differences in news consumption and comprehension between these two groups. In the following section existing literature on children as a news audience will be examined. Ultimately we focus our findings on three major themes: children's exposure to television news; their views on television news; and the role of news in the political socialization of children. Since news is positively related to civic engagement (see Carter, 2014) it is fruitful to examine how children in Albania see themselves portrayed in news coverage. Therefore results could be drawn on how children connect with society and the role that television news is playing in that respect.

\section{Children as an audience for news}

The existing research on children as a news audience has mainly focused on three areas: children's attitudes towards the news media (exposure, recall and comprehension of news items), children's emotional reactions to news coverage, and the role of news in 
political socialization and the civic engagement of children (see Alon-Tirosh and Lemish, 2014).

Research conducted on the attitudes of children towards the news media, challenges the existing perceptions that "children... regard the news as 'boring', and refuse to read newspapers, tune into television or radio news, or search out news on the internet (Carter, 2013:255). Alon -Tirosh and Lemish's (2014) study with children (aged 8-15) and youths (aged 16-18) in Israel found that they expressed a desire to be informed on core national issues, but asked for a positive framing that removed the scary and gory elements.

Moreover, previous research carried out with kindergarten children in the US and Israel (Lemish, 1998) found that the participants were interested in the news and this interest was closely related either to the sociopolitical context of the country (the case of Israeli children), or to parental mediation (the case of children in the US). Additionally, Carter, Davies, Allan, Mendes, Milani, and Wass (2009) found that the majority of children aged 8-15 surveyed in the UK, considered the news to be interesting (96.8\%) and more than half of the sample 112 children - mentioned TV as their 'favorite place for news'. Furthermore, Ponte (2008) by interviewing 500 children of different ages, concluded that they showed great enthusiasm on following both adult and children's news.

The second body of research has explored children's emotional reactions towards news content. Within these studies, there is a diverse body of knowledge that attempt to explore such reactions. Some studies (Eron, 1963; Huesmann and Eron, 1986), employ a psychological perspective and make use of experiments as a method for research. This kind of research dates back to the 60 s and 70 s due to the prevailing discourses in that period on television's negative influences on children (Eron, 1963; Huesmann and Eron, 1986). Adoni \& Cohen (1980) documented that children show fear or anxiety when exposed to news items related to the coverage of war, which was a prevailing topic of research in the following years (Cantor and Nathanson, 1993; Walma van der Molen et al., 2002; Blankenmeyer, Walker and Svitak, 2009). Other studies have employed a social approach which acknowledges children's agency in their use and consumption of television news and has used qualitative methods as a tool for research. These studies show that children are able to engage in a more critical way with the news media if news is constructed with children as an audience in mind (Carter, 2014; Lemish and Gotz, 2007). Recently, there is a growing body of research that makes a combination of both approaches, by exploring children's fright reactions to news media from a psychological approach while making use of qualitative techniques (see Riddle, 2012; Riddle et al., 2012).

The ways in which children engage with the news media brings us to the third group of research: the role of the news media in introducing children to civic engagement.

According to Patterson (2007:5), "there is evidence that news habits developed early in life effect later use that appeal[s] to civic virtue". Earlier studies have suggested that children who watched the news more frequently, were more knowledgeable about the political 
world, demonstrated greater curiosity towards the news, and were more motivated to actively pursue additional information (Atkin and Gantz, 1987). Recent studies have documented that viewing both traditional forms of news and nontraditional sources of political information (late-night comedy shows) increases children's internal political efficacy, which in turn positively predicts their civic participation (Hoffman and Thomson, 2009). Additionally, authors have sought to research the news media's perception of children's place in the world and how it shapes their understanding of citizenship (Livingstone, 2002; Buckingham, 2000). It is argued that if the news media became more accessible to children, their participation in the public sphere would be enhanced.

This study aims to explore children's views on their representation in television news in Albania, in their own words. Additionally, the perspectives of adults on the representation of children are explored. While research has shown that children see themselves as being excluded from the typically adult-centered news outlets and that their perspectives are not taken into consideration (Ponte and Aroldi, 2013; Carter et al., 2009), there has been no research conducted which relates to the views of adults on how children are being represented in the news. Keeping in mind the news media's ability to strengthen civic participation, exploring the views of children and adults as it pertains to the news media is crucial.

\section{Methodology}

This study included a multi-method exploration of children's and adults' views on television news in Albania, with a special focus on the portrayal of children, by using questionnaires, focus group interviews and custom-designed activities. In total, 118 participants, including 64 children (aged 10-15) and 54 adults (aged 26-62), were interviewed in 12 focus groups; 6 with children and 6 with adults, with 8-12 participants each. We collaborated with the Education projects' team of World Vision Albania and Kosova (WVA\&K)- an international children's rights organization - to conduct the focus groups. ${ }^{1}$ The approach of the organization is to build and empower community groups that are then engaged in the implementation of several development projects. We made use of the routine meetings of these community groups. Parental consent was required for all children who participated. Children's groups were balanced ( $50 \%$ boys and $50 \%$ girls), while a bigger participation among women (74.1\%), was noted in the adult groups. This could be explained by the higher availability of women to participate in activities of this type when compared to men, due to a higher unemployment rate among this group in Albania (Rusi and Mustafaj, 2013). 12 of the participants in the adults focus groups were teachers $(N=54)$. Nonetheless all participants in the focus group were asked to reflect on the topic of discussion in their position as parents or adults- in case they had no parenting experience. In two of the groups 
- one for adults and one for children - representatives from cultural minorities, including Roma and Egyptians, participated. The focus groups took place in five regions of Albania: Durres, Tirane, Elbasan, Shkoder and Lezhe, from May to June 2015.

The decision to have separate groups for children and adults comes as a reflection on the fact that children's perspectives may be different from adults' accounts and thus should be elicited directly from children, while minimizing the risk for adults' intervention (see Balen et al., 2006). While the decision to recruit participants who are already accustomed to each other was taken after consulting literature on the topic which states that the social environment impacts the ability for people to express themselves (Lindlof and Taylor, 2011). The meetings lasted approximately two hours and were digitally recorded and transcribed verbatim.

All focus groups started with a drop-off questionnaire as a way to get some demographic data on the participants. On the same time it served as a warm up exercise, having in mind that subsequent activities required an active participation. Considering the number of participants in each group, the facilitator ${ }^{2}$ read aloud all questions and the participants were invited to address any misunderstanding to the facilitator, directly. All participants confirmed to have understood all questions before filling in the questionnaire.

Two slightly different questionnaires were developed for children and adults. For each template, specific questions on demographic data were asked (name, age, city/village, and profession for adults) and children's and adults' news viewing habits (where, when, what, why). The adults' questionnaire comprised several additional questions on parental involvement in news consumption and the extent to which they encouraged children to follow news. On the other hand the questionnaires of children posed additional questions on the quality of children's portrayal in television news and the extent to which they felt represented in such portrayals. In addition, both children and adults were asked to recall and write down a news item on children that they recently watched on television.

Additionally, participants were presented with two activities that were customdesigned for the study. In the first activity, participants were introduced to 10 pictures, five of which showed newscasters, and were then asked to identify the newscasters and provide additional details for each of them. In the second activity, the participants were presented with a list of 11 news items taken from actual news broadcasts, including two news items related to children. Participants were first asked to list the news items as they would appear in an actual news broadcast and then asked list the news items as the group members would like to see them broadcasted - starting from what they considered as the most important. These activities had two purposes. First, they aimed to explore the participants' exposure and familiarity with television news. Second, they aimed to explore their views on the importance of news items on children. Using creative techniques, especially research with 
children, is a method that is being encouraged in social science research (see O'Cane, 2000). Consequently, it generates insights into children's perspectives, while empowering them for a fuller participation.

Subsequently, participants watched three news items related to children, taken from actual news broadcasts. These items belonged to the three topics where children appeared to be more present in television news in Albania: children as victims, as objects of emotional appeal and children as performers and were chosen based on an extensive media monitoring process conducted earlier (see Kaziaj, 2016). After each item, the facilitator asked children and adults their opinions of the news item in general (Is the topic clear? Is it interesting?) and the portrayal of children in particular (How does this news item make you feel? Is it representative of children? What is missing? Why?). Notes from the discussions served as the main data for the analysis, complemented by data from the questionnaires and meticulous expressions and results from the card activities.

This study belongs to what Jensen (2011) assesses as the third group of reception studies, whose concern is to investigate how concretely the media is integrated into both everyday life and various institutionalized practices. Discursive elements on news stories related to children are taken as the basis to trace the presence of particular themes and their reproduction by the audience. These discourses provided further insights on the role of news as a social action. Analysis of the responses from the focus group discussions supplemented with qualitative data from the card activities were subjected to a grounded analysis of emerging themes, using qualitative content analysis procedures (Lindlof and Taylor, 2011). Additionally demographic data from the questionnaires served as complementary to qualitative findings, to provide additional information on the characteristics of both groups.

\section{News consumption and recall}

The most dominant finding from the discussions with children and adults was that both groups are exposed to television news, almost every day. Regardless of the fact that adults reported watching the news more often than children, the two card-activities that were conducted with children and adults revealed additional aspects. In the first activity, in which children and adults were asked to identify the newscasters based on the photographs provided; all groups of children were able to distinguish the newscasters from the nonnewscasters. Furthermore, children were able to provide additional details on the newscasters, such as the television channel that they work for and in some cases the names of the newscasters. Surprisingly, none of the adult groups were able to identify all of the newscasters. Most of them were able to identify only two out of five newscasters and in most cases they confused actors, or political analysts with newscasters. Furthermore none of the adult groups were able to name any of the newscasters. These findings could be 
explained by the fact that children in general show a better ability than adults to recall visual information related to television news (Walma van der Molen and van der Voort, 2000). Additionally, when children and adults were asked to write a news item on children that they recently watched on television, only $37,5 \%(N=64)$ of children answered that 'they don't remember any news item' while the percentage of adults that could not remember a news item was significantly higher, $53.5 \%(\mathrm{~N}=54)$. The high percentage of children and adults that could not recall a news item related to children is related to the fact that news items on children are difficult to find on television news outlets in Albania (Kaziaj, 2016). Nonetheless, $84.4 \%$ of children and $85.2 \%$ of adults reported that they would be interested in watching more news items related to children. These finding is in alignment with previous studies conducted on the same topic which contradict the belief that children are not interested in television news (Alon- Tirosh and Lemish, 2014; Carter et. al, 2009).

In the focus groups, adults reported instances of news items that had become vigorous topics of discussion in the past. One teacher said:

"I remember one morning entering the class and the pupils immediately asked if I had seen the news of the previous day about two sisters that were kept in chains by their parents. I immediately checked for it in the newspapers when the lesson was over"." (man, Lezhe, 31).

Another participant said that for several days children discussed a news item about a pupil being spanked by his teacher"

"I could see them watch the video on their mobile phones and comment it with each other" (woman, Lezhe, 45).

Children from the Shkoder focus groups brought up this case. When asked about their choice to discuss this particular item, they said:

"Because that teacher was in our school" (Boy, 10 years, Shkoder) and "because we are curious to know why would someone do such a thing as abusing a child" (Girl, 13, Shkoder).

The discussion about the video opened up a debate in the group concerning whether the video should or should not have been broadcast by the news media. One girl was against the broadcast of this video:

"I think it was not right that the media broadcast the video because the teacher was filmed inappropriately. The teacher is 'a second parent' and she just used different 
methods to educate that child. I am sure that she didn't do it just for fun." (girl, 12, Shkoder).

On the other hand, one of her classmates contested her by saying:

"I think it was right that the news media broadcast the video because the child goes to school to [receive] an education and not to be abused. If the child doesn't behave well, then the teacher can call his parents, but not abuse him." (boy, 12, Shkoder).

Significantly, the girl and the boy in the above descriptions take two oppositional stands, which not only question the ethical ways in which teachers should behave, but also spell out their knowledge of what is ethical and not ethical in the news coverage. By justifying the behavior of her teacher, the girl clearly tries to show to the group and the interviewer her position as a child who is obedient to adult's rules and acknowledges them as an unquestioned authority. Her choice of words 'the teacher is a second parent' is a phrase that was frequently used in poetry about teachers during the communist era (before the 90s). The boy on the other hand, refuses to take the role of the 'obedient child' in relation to teachers, but still positions himself under adult supervision, namely, his parents. Even though both children express different opinions on the ethical behavior of news media, they share the same viewpoint related to their relationship with adults namely, that children need to submit to adult's supervision. This is in coherence with the news media's representation of children which reinforces an adult perspective on children (Kaziaj, 2016).

It is interesting to note that several examples brought up in discussions in both groups, children's and adults', were related to children as victims. One explanation could be that news items on crime and violence are more often found in Albania's television news media when compared to other topics (idem). Furthermore, in both cases we can see that proximity (Galtung and Ruge, 1965) plays an important role in news items that children choose to discuss. According to Alon-Tirosh and Lemish (2014), research shows that children express anxiety over more concrete threats to themselves and their loved ones. This points to the importance of the ethical coverage of children in news and the need to avoid scary elements or unjustified details on the victims, redundantly used in news media.

\section{Children's presence and voice in the news}

This study explored television news with a special focus on news items related to children. On these grounds, children and adults were asked about their perception of the broadcast frequency of these news items. The majority of children $56.3 \%(\mathrm{~N}=64)$, answered that 'there is less than one news item on children per week'. A considerable percentage of children, $32.8 \%(\mathrm{~N}=64)$ believed that 'there is at least one news item on children per week'. Three children or $4.6 \%(\mathrm{~N}=64)$ believed that 'there are no news items on children at all on television'. In general adults reported similar perceptions, but 10 adults, or $18.5 \%(N=54)$ 
believed that 'there are no news items on children at all on television'. This is a much higher percentage than in the case of children. International research findings on the representation of children in news confirms that children are often absent from news coverage (Carter, 2014; Ponte, 2008).

Focus group discussions provided a deeper understanding on the views for the lack of children's presence in television news coverage. When children were asked 'why do you think there are fewer news items about children' some responded:

"Because news [outlets] deal more with politics, and children are of no special interest to the news" (girl, 11, Durres).

"I think news [stories] are organized only for the people who have influence. If we organize an activity in our school, nobody cares about it, but if a politician or someone famous joins the activity, then the news media will for sure broadcast the activity". (boy, 12, Shkoder)

Children attributed their lack of presence in news coverage to the fact that news media outlets in Albania offer an overwhelming amount of attention to politics and political actors. As such, children are not considered to be interesting news subjects. The two quotes above suggest that children recognize the existence of a hierarchy of news values (Harcup and O'Neill, 2001) in Albanian television news. They see themselves as being positioned at the bottom of this hierarchy and they acknowledge their powerlessness in comparison to adults.

Adults shared the same opinions for the lack of children's presence in the news media:

"Once, a journalist came to us for the celebrations for the $1^{\text {st }}$ of June", and started asking questions about local elections". (woman, 40 , Durres)

"I have never seen a news item with just children celebrating. There must be either the presence of a politician, or a foreign ambassador, mostly the American ambassador, so that the news media reports on that activity!" (man, 33, Tirane).

Reports on media in Albania highlight the disproportionate presence of political actors as a serious issue that can harm the independence of the news media. As a monitoring report from the Balkan Media Barometer (Lani, 2013) states, 'media outlets in Albania are increasingly becoming similar to political parties'. This perception questions the role of the news media in Albania to provide a platform for citizen-participation, particularly 
their encouragement of the participation of children.

Furthermore, adults argue that there is a hierarchy in news items related to children. News coverage mostly features activities related to children in the capital of Tirana, or news items on children from cultural minorities, such as Roma or Egyptian, which mostly cover topics of poverty or trafficking. According to adults, children from rural areas are rarely present in television news:

“Children from rural areas organize lots of activities, but they don't appear in television news [broadcasts]. The news media is not interested in children from rural areas, they are abandoned" (woman, 47, Elbasan).

This perception is confirmed by recent findings from a monitoring process of news in Albania, where only seven news items out of 157 focused on children from rural areas, while 94 news items from the same sample focused on children or events taking place in Tirana, the capital (Kaziaj, 2016).

Furthermore, children and adults report that they rarely see children being quoted in television news coverage. One of the girls, who was once interviewed for a news event, described her experience by saying:

"I was interviewed for an activity that we organized with other schools in Tirana. When I went to school the next day I was famous. It is one of the best experiences of my life" (girl, 11 Durres).

This statement clearly shows the significance of such an event, and illustrates the impact it can have on the life of a child. None of the other children present had anything to add after the girl shared her experience. It seemed as if the fact that she had been interviewed for television news gave her a special status among her peers and she took a leading role in the discussions. This points to the need and importance of the news media to provide a voice for children and to influence the ways they see themselves being involved in activities that are happening around them. As previous research has found, children use the news media as one of the strategies for understanding the world around them and their place in the world (Carter and Alan, 2005; Livingstone, 2002; Buckingham, 2000).

\section{Children, news and politics}

In order to grasp a holistic understanding of children's and adult's opinions on the quality of children's portrayal in television news, participants were presented with three news items where children appeared as subjects and were invited to share their thoughts on the portrayal of children.

Among participants, children stated that news coverage enforces the idea that only children who live in the capital are active and engaged in activities occurring in schools or 
communities. Further, the participants stated that, other children are quite invisible and journalists are not interested in their stories. According to a girl:

"The only case when journalists came to my town was when a newly married girl killed her mother- in law" (girl, 14, Tirane ${ }^{6}$ ).

Additionally, children stated that the media generalizes certain phenomena related to their age group. According to them, media coverage often portrays older children (14 and up) as being abusive of alcohol and drugs, or in engaging in promiscuous sexual relationships. As one boy participating in the focus groups in Tirana said:

"This is wrong, as this judgment is based only on what journalists perceive" (boy, 15, Tirane).

Furthermore, children were able to assess how their portrayal in the news affects the ways adults think of them. A boy that participated in the focus group discussions in Tirana, where some of the participants belonged to the Roma community, said:

"When we see Roma children begging in the news, people think, 'well it is always like this with Roma children as they have nothing better to do'. But this happens because there is no other news items on Roma children rather than begging" (boy,13, Tirane) . According to the children:

"The news aims to attract people's attention and that is why they come up with emotional items" (girl, 11,Shkoder).

"The news targets an adult audience and by portraying children as victims they try to appeal to their parents and not to the children themselves" (boy, 15, Tirane).

As the above examples show, most children evaluate their portrayal in television news coverage as negative. This was the case for a previous study conducted in Albania with older children aged, 13-18 (Nelaj, 2014) in which they assessed their portrayal in the media as negative, namely: disorganized, intolerant and violent. Although this study did not consider children's portrayal in news coverage, but within the media in general, it still provides some insights into how children in Albania see themselves being included in media's content. It can be said that the ways in which news coverage represents children, is harmonized with the ways children are included in the overall content of the media in Albania.

When the children were asked 'which topics are more likely to include children?' a difference was noted in the answers provided by boys and girls. Most girls mentioned topics 
that can be considered hard news, such as crime, violence, or accidents, while boys mentioned topics that can be considered soft news, such as celebrations, or arts and culture. This apparently surprising finding is supported by results from a 2016 monitoring study (Kaziaj,2016), which found that boys were mostly portrayed as objects of emotional appeal in television news coverage in Albania, while girls were mostly portrayed as victims. Consequently, when girls and boys were asked to recall news items on children, they focused more on news items that they perceived to be directly related to them. In a way it can be said that they have internalized the ways in which the news media portrays them.

After reviewing the transcripts from the focus group discussions, we noted a clearcut difference noted on the topics that children and adults recalled discussing more often with each other. When asked 'which news items did you discuss recently with your children?', most parents took a moralizing, educative or patronizing stand to the question. They used expressions such as:

"I discussed the exams with my child, as it is really important to make them understand that their future relies on their success in exams", or "Even though I don't like football myself I always discuss the football news with my son because I know that he likes it a lot", "I discussed a news item about ISIS, as I felt that my child was scared".

In all these expressions there is an underlying assumption that parents carry through in their answers, namely that children lack the critical thinking skills to make sense of the news. On the other hand, children answered quite differently to the question 'which news items did you discuss recently with your parents?'. Most of them recalled news items that dealt with politics (elections, corruption, politicians):

"I discussed a news item about some politicians that were accused of providing packages of flour to some people in remote areas in order to get their votes in the coming elections" (boy, 14, Shkoder).

Children frequently mentioned politics as a topic of discussion. They used the word politics as a way to refer to the actions of politicians. Furthermore, they were able to mention several cases of corruption of well-known politicians that were featured in news coverage and expressed their opinions on how such actions could have implications for the economy of the country. Such views refute the perspective that children are not interested in politics or political matters (Rideout, Foehr and Roberts, 2010). As Buckingham (1999:178) states, 'young people's cynicism about politics should be interpreted as a result of exclusion and disenfranchisement, rather than ignorance or immaturity'. The prevailing presence of politics in discussions among children might be influenced by the overwhelming presence of political actors in Albanian news coverage (Lani, 2013). Nevertheless, politics was not 
mentioned in the adult group discussions to the same extent that it was mentioned during the children's group discussions. Furthermore, children began talking about politics when asked to report on the news items they discuss more often with their parents. In the words of Buckingham (2000), this can be seen as a sign of children being urged to be 'mature' and constantly reminded that they are not free from the adult's prohibitions and controls. Children's discussions concerning political matters can be seen as a way of acquiring legitimacy from adults, by showing their 'maturity' in discussing topics that they perceive as belonging to adults. Children try to enter the public sphere, which is portrayed by the news media as being exclusively an adult domain, from which children are excluded. In doing so they ask for more consideration from media professionals in presenting their realities. As one of children participating in the discussions stated:

"We know that journalists choose certain news items on children because they want to grab the attention of their viewers, but by doing so they miss some very important aspects of 'what life is like for a child today in Albania'. It is not only about the negative phenomenon or the other extreme, celebrations, it is also about how we live our routines, what we think of it, what is missing in our lives and what can be improved!" (girl, 12, Elbasan).

\section{Conclusion}

Results from the present study shed light on children's consumption and views on television news coverage in Albania, with a special focus on their own portrayal. By putting children's views next to adults', this study explored differences among these two groups in terms of news consumption and news comprehension. There are no news services for children in Albania, therefore they are exposed to the same news programs as adults on a regular basis, as this study found. Findings suggest that both groups - children (aged 10-15) and adults (25-65) - have a considerable preference for watching television news, which they consider a very important source of information on political, social or cultural problems. Furthermore, both groups acknowledge the indifference of news media towards children. The vast majority of the participants in both groups had difficulties recalling a news item on children that they had recently seen on television. Nonetheless, an ample percentage of children and adults reported that they would be interested in watching more news items related to children. While the interest of adults in news coverage is taken for granted due to the belief that adults are main targets for news outlets, the noticeable interest of children in television news is hidden. Seeking information on issues related to politics is seen as a way of understanding one's place in society and a way of expressing a desire for civic engagement. These sentiments were further strengthened by the selection of news topics that children reported discussing more often with their parents, which were related to politics, corruption or elections. 
Children reported that they do not see themselves being represented in news coverage. According to them two categories are mostly found on news broadcasts: children from Roma or Egyptian communities; who are mostly portrayed as victims, or children living in the center of Tirana; who are mostly portrayed in celebrative events. Children who participated in this study rejected these portrayals as being representative of their realities. Furthermore, they point to the consequences that such portrayals can have to their positioning in society. They express an urgency for news to be related more to their realities and to avoid generalizations. This finding lends support to other research studies, which argue that news coverage portrays children in limited frames, and does not take their perspectives into consideration (Carter, 2014; Ponte \& Aroldi, 2013). Findings need to be related to the context of the news media in Albania, which is reportedly squeezed in between the political and business interests of a bunch of media tycoons (Halo, Hyseni, Matlija and Aleksandridis, 2015). As such, the news media is centered around politics and political actors rather than serving as a source of information for its citizens and being inclusive to their voices. Nevertheless, research conducted in other countries has also found that children and their issues are almost invisible in news media coverage, and that media outlets do not provide a platform for children to participate (Carter, 2014, Ponte, 2007; Fullertone, 2004). As such, findings from this study could appeal to media professionals to begin considering children both as an audience and subjects for their daily work. Being inclusive to children's perspectives would enhance their civic engagement, while diversifying sources of news coverage for a larger audience. Additionally, children's views on the news media and their attitudes towards such a medium could be used by researchers, policymakers or children's rights activists to seek more consideration of children's' perspectives as a way of fulfilling their right to participation and facilitating their presence in the public sphere, as a fundamental right for democratic societies.

\section{Notes}

1. One of the authors was part of this organization, from 2009-2013.

2. One of the authors traveled to Albania for this purpose and facilitated all the focus groups.

3. News item broadcasted, Oct 28, 2009.

4. News item broadcasted, Oct 16, 2015.

5. Celebrated as 'The Children's Day' in all schools in the country.

6. The case that the girl recalls happened in Peshkopi, her home town. 


\section{References}

Adoni, H. and Cohen, A. A. (1980). Children's fear responses to real- life violence on television: the case of the 1973 Middle East war. Communications, 6 (1), 81-93.

Alon-Tirosh, M. and Lemish, D. (2014). If I was making the news: What do children want from news? Participations: Journal of Audience and Reception Studies, Vol. 11 (1), 108-129.

AMA (2014). Kodi i Transmetimit. Tirane: AMA

Atkin, C. and Gantz, B. (1978). Television news and political socialization. Public Opinion Quarterly, 42, 183-197.

Balen, R., Blyth, E., Calabretto, H., Fraser C., Horrocks, C., and Manby, M. (2006). Involving children in health and social research: 'Human becomings' or 'active beings'? Childhood, 13(1), 29-48.

Blankemeyer, M., Walker, K. and Svitak, E. (2009). The 2003 War in Iraq: An ecological analysis of American and Northern Irish children's perceptions. Childhood, 16(2), 229-246

Buckingham, D. (2000). The making of citizens: Young people, news and politics. London: Routledge.

Buckingham, D. (1999). Young People, Politics and News Media: Beyond political socialisation, Oxford Review of Education, 25:1-2, 171-184.

Buijzen, M., Walma van der Molen, J. H. and Sondij, P. (2007). Parental mediation of children's emotional responses to a violent news event. Communication Research, 34 (2), 212-230.

Cantor, J. and Nathanson, A. I. (1996). Children's fright reactions to television news. Journal of Communication, 46(4), 139-152.

Carter, C. (2014). News media and Child Well-Being. In F. C. Asher Ben-Arieh, Handbook of Child Well-Being. 1979-2011. New York: Springer.

Carter, C., (2013). Children and the News: Rethinking citizenship in the twenty-first century. In Lemish (ed), The Routledge International Handbook of Children, Adolescents and Media, 255-262. Abingdon: Routledge,.

Carter, C., Davies, M. M., Allan, S., Mendes, K., Milani, R., Wass, L. (2009). What do children want from the $B B C$ ? Children's content and participatory environments in the age of citizen media. AHRC/BBC, Cardiff University. 
Carter, C. and Allan, S. (2005). Hearing their voices: Young people, citizenship and online news. In A. Williams \& C. Thurlow (eds.) Talking adolescence: Perspectives on communication in the teenage years, 73-90. New York: Peter Lang.

Carter, C. and Davies, M. M. (2005). A fresh peach is easier to bruise: children and traumatic news. In S. Allan (eds.) Journalism: Critical Issues , 224-235. Maidenhead and NY: Open University Press.

Davies, M. M. (2008). Fair and balanced reporting. Journal of Children \& Media, 2(3), 305310.

Eron, L. D. (1963). Relationship of TV viewing habits and aggressive behavior in children. Journal of Abnormal and Social Psychology, 67(2), 193-196.

Fullertone, R. S. (2004). Covering Kids: Are journalists guilty of exploiting children? Journalism Studies, 511-524.

Galtung, J. and Ruge, M.H. (1965). 'The structure of foreign news,' Journal of Peace Research, 2(1): 64-90.

Gunter, B., Furnham, A., and Griffiths, S. (2000). Children's memory for news: A comparison of three presentation media. Media Psychology, 2(2), 93.

Halo,A., Hyseni,D., Matlija, D., and Aleksandridis, T. (2015). A blind eye on news: selfcensorship in the Albanian media, Tirane: Balkan Investigative Reporting Network.

Huesmann, L. R. and Eron, L. D. (1986).Television and the aggressive child: A cross-national comparison. Hillsdale, NJ: Erlbaum.

Harcup, T., O'Neill, D. (2001). What Is News? Galtung and Ruge revisited. Journalism Studies, 2 (2), 261-280.

James, A., Jenks, C. and Prout, A., (1998). Theorizing Childhood. Cambridge: Polity.

Jensen, K.B. (2011). Media reception, in Jensen, K.B (Eds), A handbook of media and communication research, 156-170, Routledge.

Kaziaj,E. (2016). The Adult Gaze': Exploring the Representation of Children in Television News in Albania. Journal of Children and Media, 10 (4),426-442.

Kevin, D., Pellicano, F. and Scheenberger, A. (2013). Television News Channels in Europe. Brussels: European Audiovisual Observatory, European Commission. 
Lani, R. (2013). Balkan Media Barometer Albania. Tirane: Albanian Media Institute and Friedrich Ebert Stiftung.

Lemish, D. and Götz, M. (eds.) (2007). Children and media at times of war and conflict. Cresskill, NJ: Hampton Press.

Lemish, D. (1998). What is news?: A cross-cultural examination of kindergartners' understanding of news. Communication: European Journal of Communication Research, 23(4), 491-504.

Lindlof, T. R.,Taylor, B. C. (2011). Qualitative communication research methods. Thousand Oaks, Calif: SAGE.

Livingstone, S. (2002). Young People and New Media. London: Sage.

Meijer, I. C.( 2007). The paradox of popularity: How young people experience the news, Journalism Studies, Vol. 8 (1), 96-116.

Nelaj, A. (2014). Study on the use of Media in Europe. Tirane: European Commission

O'Kane, C. (2000). The Development of Participatory Techniques: Facilitating Children's Views about Decisions which Affect Them, in P. Christensen \& A. James (eds), Research with Children: Perspectives and Practices, 136-59. London: Falmer Press.

Patterson, T. E. (2007). Young People and News. The Joan Shorenstein Center on the Press, Politics and Public Policy: John F. Kennedy School of Government, Harvard University.

Piaget, J., Inhelder, ,B. (1969). The psychology of the child. New York: Basic Books.

Ponte, C. and Aroldi, P. (2013). Children's cultures and Media cultures. Communication management quarterly, $n r$ 29, 7-16.

Ponte, C. (2008). Children in the news, children and the news-Notes from a Portuguese research project. Nordicom. International Clearinghouse on Children, Youth and Media.

Ponte, C. (2007). Mapping news on children in the mainstream press. European Societies, 9 (5), 735-754.

Prout ,A. and James, A., (1997). Constructing and reconstructing childhood: contemporary issues in the sociological study of childhood. London: Falmer Press

Rideout,V., Foehr, U., and Roberts,D.( 2010). Media in the Lives of 8- to 18-Year-Olds. California: Henry J. Kaiser Family Foundation. 
Rusi, I. and Mustafaj, I. (2013). The current employment situation in Albania. The international Institute of legal and criminal studies, Pristina.

Walma van der Molen, J.H.. and van der Voort, T.H.A. (2000). Children's and adults' recall of television and print news in children's and adults' news format. Communication Research. 27 ( 2), 132-160,

Walma van der Molen, J. H., Valkenburg, P. M. and Peeters, A. L. (2002). Television news and fear: A child survey. Communications, 27, 303-317.

Wayne, M., Henderson, L., Murray, C. and Petley, J. (2008). Television and the Symbolic Criminalization of Young People, Journalism Studies 9(1): 75-90.

Van Dijk, T. A. (2008). Discourse and Power. Houndsmills: Palgrave. 